\title{
Influence of Evaporation Drying on the Porous Properties of Carbon/Carbon Composite Xerogels
}

\author{
Kriangsak Kraiwattanawong ${ }^{1, *}$, Noriaki Sano ${ }^{2}$ and Hajime Tamon ${ }^{2}$ \\ 1 Department of Chemical Engineering, School of Engineering, King Mongkut's Institute of Technology \\ Ladkrabang, Bangkok 10520, Thailand \\ 2 Department of Chemical Engineering, Kyoto University, Kyoto 615-8510, Japan; \\ sano@cheme.kyoto-u.ac.jp (N.S.); tamon@cheme.kyoto-u.ac.jp (H.T.) \\ * Correspondence: kriangsak.kr@kmitl.ac.th; Fax: +66-2-329-8360 (ext. 4)
}

check for updates

Citation: Kraiwattanawong, K.; Sano, N.; Tamon, H. Influence of Evaporation Drying on the Porous Properties of Carbon/Carbon Composite Xerogels. Polymers 2021, 13, 2631. https://doi.org/10.3390/ polym13162631

Academic Editor: Boqi Xiao

Received: 30 June 2021

Accepted: 2 August 2021

Published: 7 August 2021

Publisher's Note: MDPI stays neutral with regard to jurisdictional claims in published maps and institutional affiliations.

Copyright: (c) 2021 by the authors. Licensee MDPI, Basel, Switzerland. This article is an open access article distributed under the terms and conditions of the Creative Commons Attribution (CC BY) license (https:/ / creativecommons.org/licenses/by/ $4.0 /)$.

\begin{abstract}
Carbon/carbon (C/C) composite xerogels dried by evaporation were prepared in this study to observe the change of their porous properties and their morphology by nitrogen sorption apparatus and a scanning electron microscope. Resorcinol and formaldehyde (RF) sols as a matrix phase and cotton fibers (CF) as a dispersed phase were mixed and gelated to be CF/RF composite hydrogels. The composite hydrogels were exchanged by $\mathrm{t}$-butanol (TBA), dried by evaporation at $50{ }^{\circ} \mathrm{C}$, and carbonized at $1000{ }^{\circ} \mathrm{C}$ to become the $\mathrm{C} / \mathrm{C}$ composite xerogels. The results show that the $\mathrm{CF}$ addition does not decrease the mesoporous properties of the $\mathrm{C} / \mathrm{C}$ composite xerogels. Moreover, the $\mathrm{CF}$ addition can alleviate the pore shrinkage, and it can maintain the mesopore structure. The mesopore size and the micropore size of $\mathrm{C} / \mathrm{C}$ composites are insignificantly changed because the $\mathrm{CF}$ addition and the solvent exchange using TBA may suppress the pore shrinkage despite the gas-liquid interface existing during the evaporation drying.
\end{abstract}

Keywords: composite; evaporation drying; porous properties; carbon xerogel; nitrogen adsorption

\section{Introduction}

Organic aerogels and carbon aerogels have a high BET surface area $\left(S_{\mathrm{BET}}\right)$ and large mesopore volumes $\left(V_{\text {mes }}\right)$. They can be prepared by the sol-gel polymerization of resorcinol with formaldehyde (RF), followed by supercritical drying with carbon dioxide and carbonization under inert gas [1-8]. Their pore structure can be controlled by changing the amounts of reactants, catalysts, and water [6]. Therefore, they can be used in various applications: adsorbents, column packing materials for high-performance liquid chromatography, and electrode materials for electric double layer capacitors, and so forth. However, the supercritical drying is a sophisticated method, and the cost of supercritical equipment is expensive. RF carbon cryogels with excellent mesoporous properties are prepared by freeze drying with solvent exchange using t-butanol (TBA), and their porous properties can be controlled by the synthesis conditions [9-12]. Freeze drying is an inexpensive method, but it needs an expensive high vacuum pump and deep chiller.

Evaporation drying, a simple and very cheap method, has been used to prepare the porous carbon xerogels by Mayer et al. [13]. With the simple drying method, porous carbon xerogels have been investigated [14-25]. Many researchers have used solvent exchange in the porous development of carbon xerogels because solvent exchange can alleviate the capillary force from the gas-liquid interface, contributing to the mesoporous carbon xerogels [15-24]. Wu et al. studied the solvent species (methanol, ethanol, isopropanol) used as solvents in the preparation of alcogels [21]. Isopropanol resisted structural collapse under ambient pressure drying. Furthermore, Kraiwattanawong et al. compared the solvent species (water, ethanol, acetone, TBA, and toluene) for the preparation of carbon xerogels [25]. It was found that TBA was a suitable solvent for the preparation of mesoporous 
carbon xerogels because TBA gave low surface tension, decreasing the pore shrinkage under evaporation or vacuum drying.

Carbon/carbon (C/C) composites possess heterogeneous structures composed of a carbon matrix phase and a dispersed phase. Herein, the normal carbon cryogels prepared from the RF cryogels are applied as the carbon matrix phase, and the cotton fibers (CF) are used as the dispersed phase [26-28]. The dispersed phase can be changed by using various materials such as carbon cloth [29,30], activated carbon fibers [31], polymeric fibers [32], and cellulose [32]. The C/C composites are also studied for their mechanical properties [30,31], porous properties [26-28,31], electrochemical properties [28,33], and thermal insulation properties [34], and so forth. The $\mathrm{C} / \mathrm{C}$ composites can allow us to design the appropriate properties to solve specific scientific and engineering problems. Evaporation drying is a convenient and cheap method, and CFs are renewable, natural, and very inexpensive materials in volume. The $\mathrm{C} / \mathrm{C}$ composite xerogels are interesting for production on a commercial scale. Therefore, the aim of this work is to study the influence of evaporation drying on the mesoporosity and the microporosity of $\mathrm{C} / \mathrm{C}$ composite xerogels. CFs are used as the dispersed phase and RF sol as the matrix phase. Nitrogen adsorption apparatus is used to estimate the porous properties of $\mathrm{C} / \mathrm{C}$ composite xerogels. A scanning electron microscope (SEM) is used to investigate the mesopore structure of $\mathrm{C} / \mathrm{C}$ composite xerogels.

\section{Experimental}

\subsection{Synthesis of $C / C$ Composites}

The C/C composite xerogels can be synthesized by the sol-gel polymerization of an RF sol with CFs. The RF sol was prepared from resorcinol (Wako Pure Chemical Industries Inc.,Osaka, Japan, research grade, $99.7 \mathrm{wt} \%$ ), formaldehyde (Wako Pure Chemical Industries Inc., research grade, $37 \mathrm{wt} \%$, stabilized by $8 \mathrm{wt} \%$ methanol), sodium carbonate $\left(\mathrm{Na}_{2} \mathrm{CO}_{3}\right)(\mathrm{C})$ (Nacalai Tesque Inc., Kyoto, Japan, research grade, $\left.99.7 \%\right)$ as a basic catalyst, and distilled water $(\mathrm{W})$ as a solvent. The mixture was gelated at $25^{\circ} \mathrm{C}$ and cured at $25^{\circ} \mathrm{C}$ for one day, at $50{ }^{\circ} \mathrm{C}$ for one day, and at $85^{\circ} \mathrm{C}$ for three days. Note that the curing temperature of $85^{\circ} \mathrm{C}$ for three days increases the stiffness of the CF/RF composites. The longer the curing time, the better the stiffness obtained. The stiffness affects the strength of $\mathrm{CF} / \mathrm{RF}$ composites during drying and carbonization. If the pore structure of a $\mathrm{CF} / \mathrm{RF}$ composite collapses during evaporation due to poor stiffness, the final product will have low porosity. Good stiffness of CF/RF composites is thus required. Later the composite wet gels were cut to a thin wafer (ca. $1 \mathrm{~mm}$ thickness). They were then exchanged with TBA (Wako Pure Chemical Industries Inc., research grade, $99 \mathrm{wt} \%$ ). The fresh TBA was exchanged daily to remove water inside the $\mathrm{CF} / \mathrm{RF}$ composite hydrogels [25]. The exchanged CF/RF composites were dried in the oven at $50{ }^{\circ} \mathrm{C}$ for three days. Note that the evaporation can remove TBA within one or two days based on the synthesis conditions. Three days are enough time to dry the $\mathrm{CF} / \mathrm{RF}$ composites for every synthesis condition. Subsequently the $\mathrm{CF} / \mathrm{RF}$ composite xerogels were carbonized in a quartz reactor inside the horizontal furnace to obtain the $\mathrm{C} / \mathrm{C}$ composite xerogels [5]. Nitrogen flowed into the quartz reactor at $200 \mathrm{~cm}^{3} / \mathrm{min}$. The temperature was ramped from room temperature to $250^{\circ} \mathrm{C}$ at $250{ }^{\circ} \mathrm{C} / \mathrm{h}$, and it was maintained at $250{ }^{\circ} \mathrm{C}$ for $2 \mathrm{~h}$. Next, the temperature was increased to $1000{ }^{\circ} \mathrm{C}$ at $250{ }^{\circ} \mathrm{C} / \mathrm{h}$, and it was kept at $1000^{\circ} \mathrm{C}$ for $4 \mathrm{~h}$. Under the carbonization step, $\mathrm{CF}$ is converted to carbon fibers $(\mathrm{CaF})$. The $\mathrm{C} / \mathrm{C}$ composite xerogels synthesized by the molar ratio of resorcinol to formaldehyde $(\mathrm{R} / \mathrm{F})$, the molar ratio of resorcinol to sodium carbonate (R/C), the mass concentration of resorcinol to distilled water $(\mathrm{R} / \mathrm{W})$, and the mass ratio of $\mathrm{CF}$ to $\mathrm{RF}(\mathrm{CF} / \mathrm{RF})$ are summarized and named in Table 1. For the carbon cryogels, the exchanged $\mathrm{CF} / \mathrm{RF}$ composites were dried by the freeze-drying technique [26-28] and carbonized in the same conditions as the $\mathrm{C} / \mathrm{C}$ composite xerogels.

\subsection{Characterization}

The $\mathrm{N}_{2}$ adsorption and desorption isotherms were measured at $-196{ }^{\circ} \mathrm{C}$ by the $\mathrm{N}_{2}$ adsorption apparatus (BEL Japan Inc., BELSORP-mini). $S_{\text {BET }}$ was calculated by the 
$\mathrm{N}_{2}$ adsorption isotherm branch. The mesopore size distribution (MesPSD), the $V_{\text {mes }}$ value, and the mesopore radius $\left(r_{\mathrm{p}}\right)$ were calculated by the Dollimore-Heal method [35]. From the MesPSD curve, the mesopore radius at its highest peak $\left(r_{\text {mes,peak }}\right)$ was observed, representing as an average $r_{\mathrm{p}}$ value. The micropore volume $\left(V_{\mathrm{mic}}\right)$ was estimated by the Dubinin-Radushkevich method [36]. The t-plot method [37] was utilized to estimate the micropore surface area $\left(S_{\text {mic }}\right)$. The HK method [38] was used to calculate the micropore diameter $\left(D_{\mathrm{p}}\right)$ and the micropore size distribution (MicPSD). From the MicPSD curve, the micropore diameter at its highest peak ( $\left.D_{\text {mic,peak }}\right)$ was investigated and used as an average $D_{\mathrm{p}}$ value. The structure of the $\mathrm{C} / \mathrm{C}$ composites was observed by field emission scanning electron microscope (JEOL, JSM-6700F). The SEM images were observed without platinum coverage because the $\mathrm{C} / \mathrm{C}$ composites had electrical conductivity.

Table 1. Nomenclatures of C/C composite cryogels prepared under various synthesis conditions.

\begin{tabular}{|c|c|c|c|c|c|}
\hline Symbol & $\begin{array}{l}\text { CF/RF } \\
\text { (g/g) }\end{array}$ & $\begin{array}{c}\mathrm{R} / \mathrm{C} \\
(\mathrm{mol} / \mathrm{mol})\end{array}$ & $\mathrm{R} / \mathrm{W}\left(\mathrm{g} / \mathrm{cm}^{3}\right)$ & $\begin{array}{c}\mathrm{C} / \mathrm{W} \\
\left(\times 10^{5} \mathrm{~mol} / \mathrm{cm}^{3}\right)\end{array}$ & $\begin{array}{l}\text { Drying } \\
\text { Method }\end{array}$ \\
\hline A00 & 0.00 & 200 & 0.50 & 250 & Evaporation \\
\hline A05 & 0.05 & 200 & 0.50 & 250 & Evaporation \\
\hline A10 & 0.10 & 200 & 0.50 & 250 & Evaporation \\
\hline $\mathrm{ACC}$ & 0.00 & 200 & 0.50 & 250 & Freeze drying \\
\hline B00 & 0.00 & 200 & 0.25 & 125 & Evaporation \\
\hline B05 & 0.05 & 200 & 0.25 & 125 & Evaporation \\
\hline B15 & 0.15 & 200 & 0.25 & 125 & Evaporation \\
\hline B25 & 0.25 & 200 & 0.25 & 125 & Evaporation \\
\hline $\mathrm{BCC}$ & 0.00 & 200 & 0.25 & 125 & Freeze drying \\
\hline $\mathrm{CO0}$ & 0.00 & 500 & 0.25 & 50 & Evaporation \\
\hline C05 & 0.05 & 500 & 0.25 & 50 & Evaporation \\
\hline C15 & 0.15 & 500 & 0.25 & 50 & Evaporation \\
\hline $\mathrm{C} 25$ & 0.25 & 500 & 0.25 & 50 & Evaporation \\
\hline $\mathrm{CCC}$ & 0.00 & 500 & 0.25 & 50 & Freeze drying \\
\hline
\end{tabular}

\section{Results and Discussion}

\subsection{Morphology of C/C Composite Xerogel}

The microstructures of carbon cryogels, the carbon xerogels, and the $\mathrm{C} / \mathrm{C}$ composite xerogels are observed, and the SEM images are presented in Figures 1 and 2. The carbon structure of carbon cryogels, carbon xerogels, and the $\mathrm{C} / \mathrm{C}$ composite xerogels consist of nanoparticles forming the mesopores. The carbon structure of carbon cryogels is similar to the carbon structure of carbon xerogels and $\mathrm{C} / \mathrm{C}$ composite xerogels. Although freezedrying can reduce the pore collapse by sublimation, evaporation drying can suppress pore shrinkage due to the vapor-liquid interface forming the capillary force. If the solvent (water) is not exchanged by TBA, water inside the tiny pores generates large surface tension during evaporation drying, ruining the pore network [25]. TBA has low surface tension, decreasing the capillary effect in the tiny pores [25]. When the evaporation is applied to the $\mathrm{CF} / \mathrm{RF}$ composites, the gel network of $\mathrm{CF} / \mathrm{RF}$ composites can resist the pore collapse as well.

By using $\mathrm{R} / \mathrm{C}=500 \mathrm{~mol} / \mathrm{mol}$ and $\mathrm{R} / \mathrm{W}=0.25 \mathrm{~g} / \mathrm{cm}^{3}$, the carbon cryogel, the carbon xerogel, and the $\mathrm{C} / \mathrm{C}$ composite xerogels have large nanoparticles, as shown in Figure 2, because the high $\mathrm{R} / \mathrm{C}$ ratio can contribute such large nanoparticles [12]. The gel-network of carbon cryogels, the carbon xerogels, and the $\mathrm{C} / \mathrm{C}$ composite xerogels are slightly shrunk by the evaporation. This result can be explained by the fact that the carbon gel preparation at a high $\mathrm{R} / \mathrm{C}$ ratio gives low shrinkage of the microstructure [8]. Therefore, the SEM images can confirm that the preparation of $\mathrm{C} / \mathrm{C}$ composite xerogels does not result in a change in their porous structure from the normal carbon xerogels at a high $\mathrm{R} / \mathrm{C}$ ratio. 

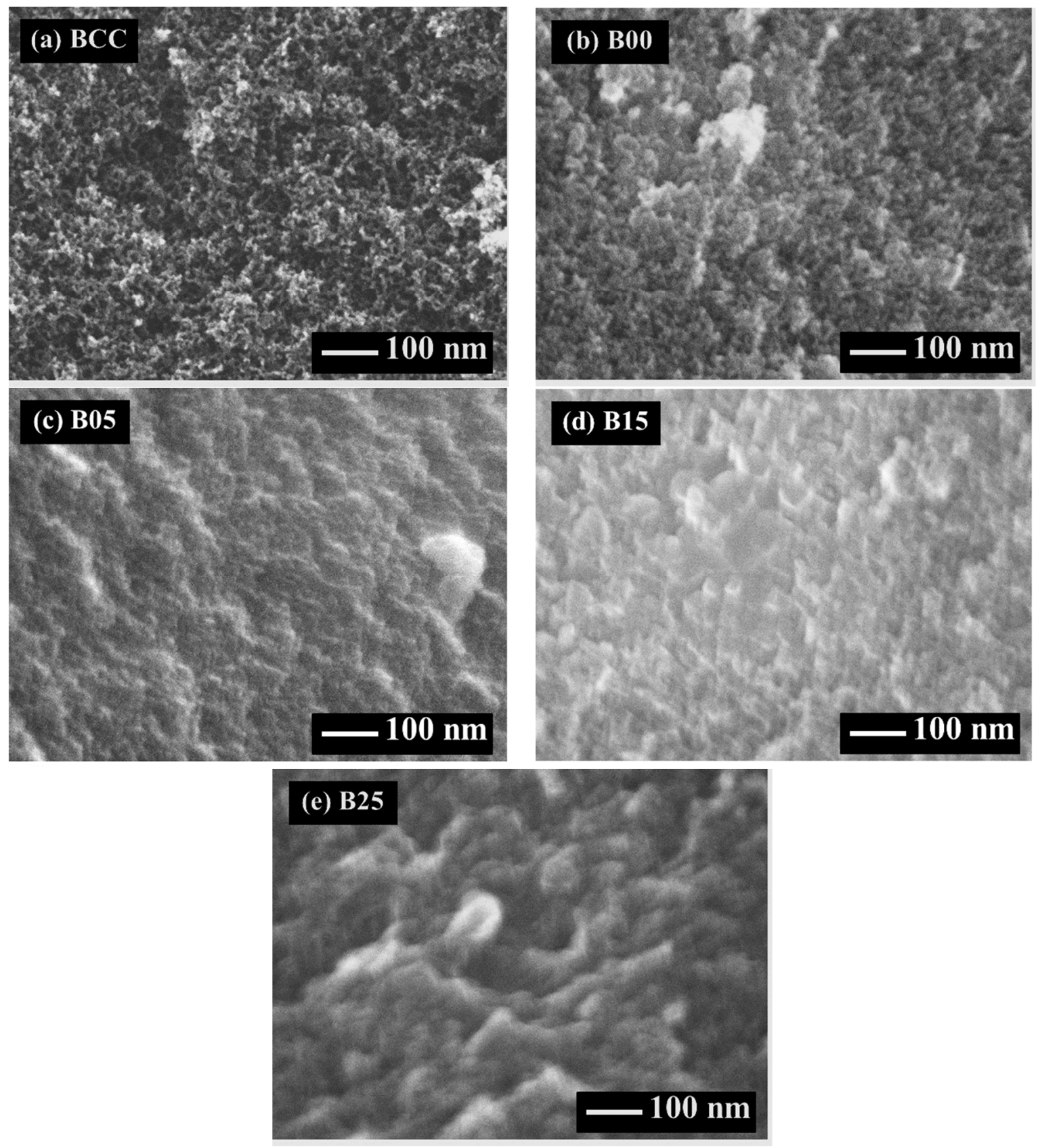

Figure 1. SEM images at $100,000 \times$ magnification of mesoporous carbon prepared at $\mathrm{R} / \mathrm{C}=200 \mathrm{~mol} / \mathrm{mol}$ and $\mathrm{R} / \mathrm{W}=0.25 \mathrm{~g} / \mathrm{cm}^{3}$ : (a) carbon cryogel, (b) carbon xerogel, (c) C/C composite xerogel at CF $/ \mathrm{RF}=0.05 \mathrm{~g} / \mathrm{g},(\mathrm{d}) \mathrm{C} / \mathrm{C}$ composite xerogel at $\mathrm{CF} / \mathrm{RF}=0.15 \mathrm{~g} / \mathrm{g}$, and (e) $\mathrm{C} / \mathrm{C}$ composite xerogel at $\mathrm{CF} / \mathrm{RF}=0.25 \mathrm{~g} / \mathrm{g}$.

\subsection{Porous Properties of C/C Composite Xerogels Dried by Evaporation Drying}

Figure 3 shows the $\mathrm{N}_{2}$ adsorption analysis of $\mathrm{CaF}, \mathrm{ACC}$, and $\mathrm{C} / \mathrm{C}$ composite xerogels at $-196{ }^{\circ} \mathrm{C}$, consisting of the $\mathrm{N}_{2}$ adsorption and desorption isotherms, MesPSD, and MicPSD. In Figure 3a, the type-I isotherm of $\mathrm{CaF}$ suggests that $\mathrm{CaF}$ contains micropores. Besides, the small hysteresis loop of $\mathrm{CaF}$ hints that $\mathrm{CaF}$ has few mesopores. Contradictorily, Figure $3 \mathrm{a}$ also reveals the type-IV isotherms of $\mathrm{C} / \mathrm{C}$ composites having micropores and mesopores similar to the type-IV isotherms of ACC. Herein, at the high relative pressure, the $\mathrm{N}_{2}$ amounts adsorbed on ACC are less than the adsorbed $\mathrm{N}_{2}$ amounts on A00. This result suggests that the porosity of ACC is less than the porosity of A00, but this consequence will be discussed later. Figure $3 \mathrm{~b}$ demonstrates the MesPSD curve of the $\mathrm{CaF}$ and $\mathrm{C} / \mathrm{C}$ 
composites estimated by using the DH method to the adsorption branch. The MesPSD curve of $\mathrm{CaF}$ confirms that $\mathrm{CaF}$ has few mesopores corresponding to its $\mathrm{N}_{2}$ adsorption isotherm. The MesPSD curve of ACC is identical to the MesPSD curve of $\mathrm{C} / \mathrm{C}$ composite xerogels, but the MesPSD curve of ACC is the lowest. Among the $\mathrm{C} / \mathrm{C}$ composite xerogels, MesPSD of A00 is similar to MesPSD of A05 and A10. Therefore, in these specimens, not only does the $\mathrm{CF}$ addition in the preparation of $\mathrm{C} / \mathrm{C}$ composite xerogels maintain the pore network, but the $\mathrm{CF}$ addition also increases the mesoporosity with a low production cost. Figure $3 \mathrm{c}$ shows the MicPSD curve of the $\mathrm{CaF}$ and $\mathrm{C} / \mathrm{C}$ composite xerogels calculated by using the HK method to the adsorption branch. The MicPSD curve of CF suggests a bimodal micropore structure, while the MicPSD curves of ACC and A00 indicate a uniform structure. When the $\mathrm{C} / \mathrm{C}$ composite xerogels are prepared, the MicPSD curve of A00 is the same as the MicPSD curve of A05, while the MicPSD curve of A10 becomes broad.
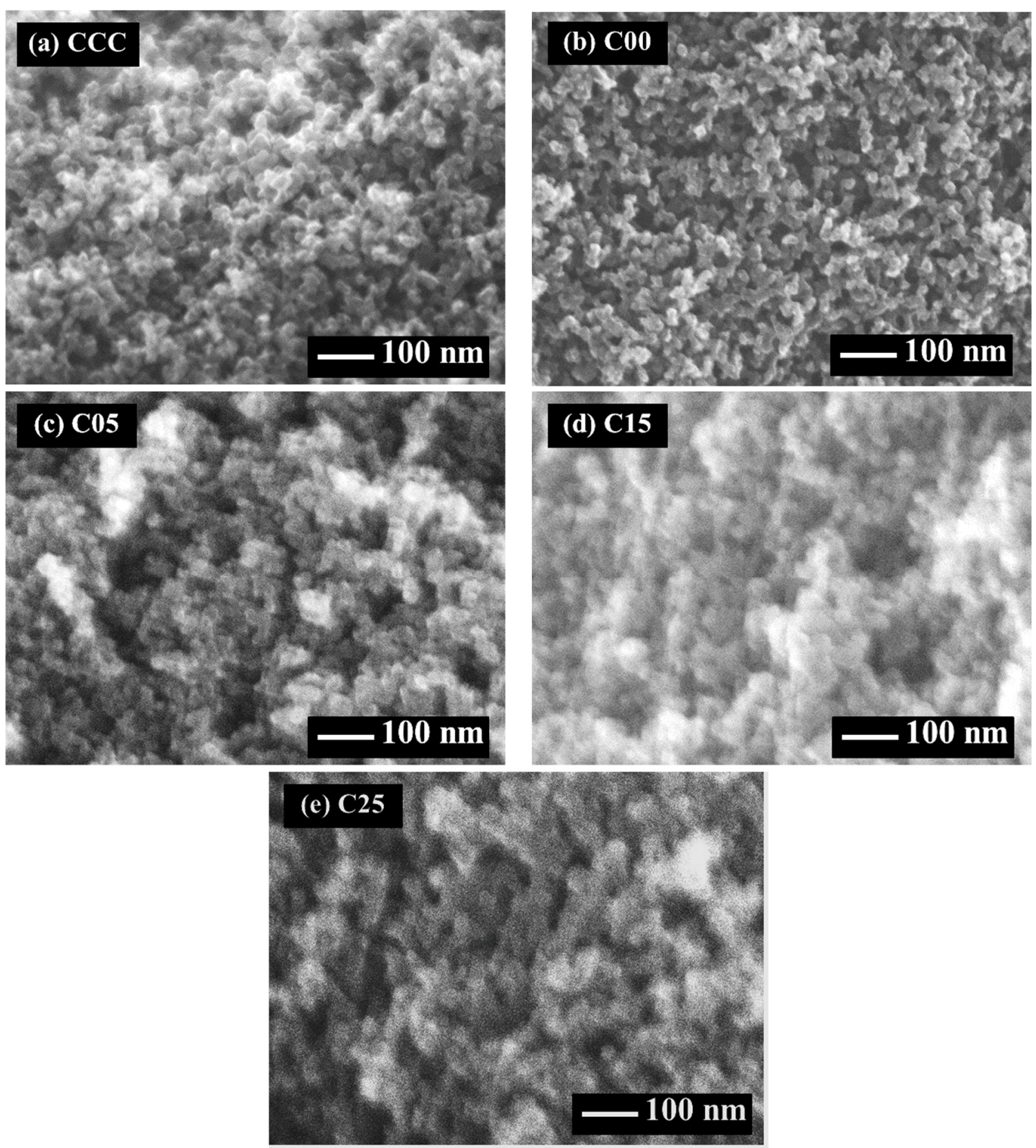

Figure 2. SEM images at $100,000 \times$ magnification of mesoporous carbon prepared at $\mathrm{R} / \mathrm{C}=500 \mathrm{~mol} / \mathrm{mol}$ and $\mathrm{R} / \mathrm{W}=0.25 \mathrm{~g} / \mathrm{cm}^{3}$ : (a) carbon cryogel, (b) carbon xerogel, (c) C/C composite xerogel at CF $/ \mathrm{RF}=0.05 \mathrm{~g} / \mathrm{g},(\mathrm{d}) \mathrm{C} / \mathrm{C}$ composite xerogel at $\mathrm{CF} / \mathrm{RF}=0.15 \mathrm{~g} / \mathrm{g}$, and (e) $\mathrm{C} / \mathrm{C}$ composite xerogel at $\mathrm{CF} / \mathrm{RF}=0.25 \mathrm{~g} / \mathrm{g}$. 

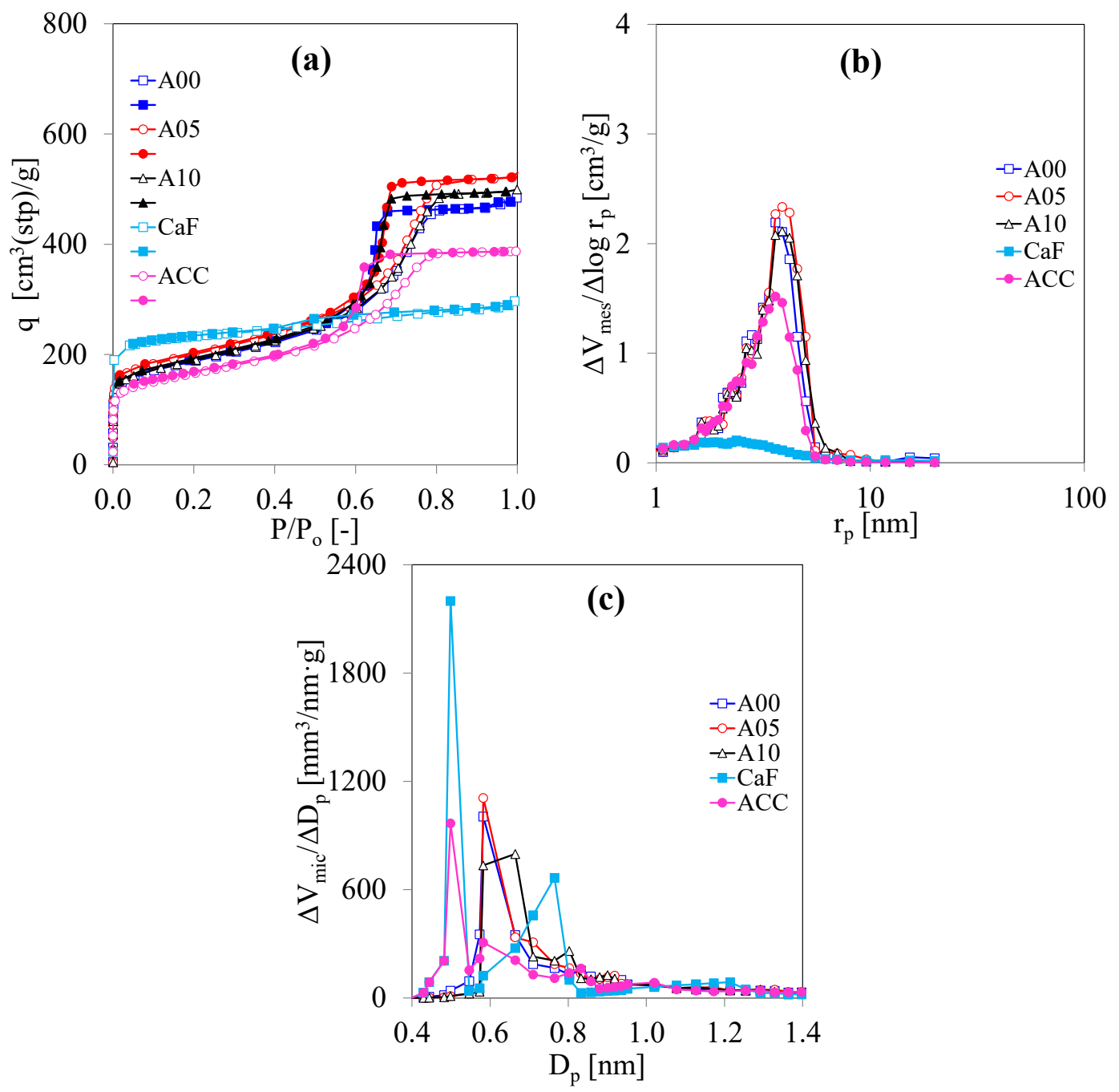

Figure 3. $\mathrm{N}_{2}$ adsorption analysis of $\mathrm{CaF}$ and $\mathrm{C} / \mathrm{C}$ composite xerogels prepared by using the $\mathrm{CF} / \mathrm{RF}$ ratio for $0.00-0.10 \mathrm{~g} / \mathrm{g}$ at $\mathrm{R} / \mathrm{C}=200 \mathrm{~mol} / \mathrm{mol}$ and $\mathrm{R} / \mathrm{W}=0.5 \mathrm{~g} / \mathrm{cm}^{3}$ : (a) $\mathrm{N}_{2}$ adsorption and desorption isotherms at $-196{ }^{\circ} \mathrm{C}$ (open symbols = adsorption; closed symbols = desorption), (b) mesopore size distribution, and (c) micropore size distribution.

Figure 4 demonstrates the $\mathrm{N}_{2}$ adsorption analysis of the $\mathrm{BCC}$ and $\mathrm{C} / \mathrm{C}$ composite xerogels. The amounts of $\mathrm{N}_{2}$ adsorbed on $\mathrm{BCC}$ at a high relative pressure is large, as shown in Figure $4 \mathrm{a}$, whereas the amounts of $\mathrm{N}_{2}$ adsorbed on B00 are smaller. In this synthesis condition, freeze-drying can maintain the porosity of carbon gel better than evaporation drying. This may be because freeze-drying generally inhibits the microstructure collapse well, while evaporation drying cannot avoid the gas-liquid interface inducing pore shrinkage. This result is related to previous works $[16,25]$. By the CF addition for the preparation of $\mathrm{C} / \mathrm{C}$ composite xerogels, the amounts of $\mathrm{N}_{2}$ adsorbed on B05, B15, and $\mathrm{B} 25$ are larger than the amounts of $\mathrm{N}_{2}$ adsorbed on B00; consequently, the porosity of B05, B15, and B25 are higher than the porosity of B00. These results imply that the CF addition helps the evaporation drying to increase the porous properties of $\mathrm{C} / \mathrm{C}$ composite xerogels. Figure $4 \mathrm{~b}$ shows that the MesPSD curve of BCC is uniform, but the MesPSD curves of C/C composites are rather broad with a smaller $r_{\text {mes,peak. This is because evaporation drying }}$ allows pore shrinkage due to the capillary force. However, the solvent exchange by TBA can decrease pore collapse [25]. For Figure 4c, although evaporation drying decreases the average micropore size of C/C composite xerogels to $0.573 \mathrm{~nm}$ and $0.582 \mathrm{~nm}$, freeze-drying can contribute to a large average micropore size at $0.664 \mathrm{~nm}$. This result is also influenced by the drying method. 


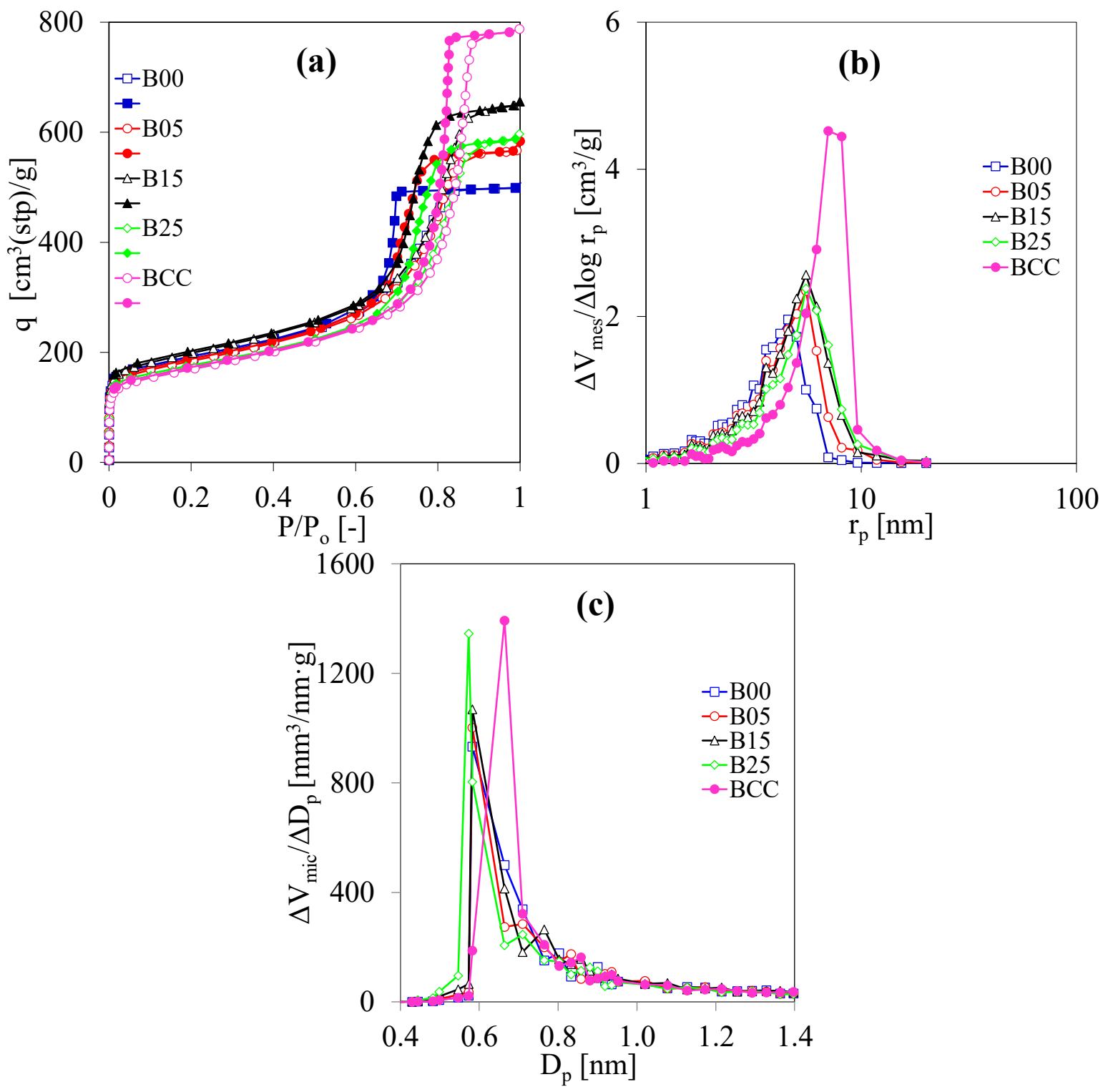

Figure 4. $\mathrm{N}_{2}$ adsorption analysis of $\mathrm{CaF}$ and $\mathrm{C} / \mathrm{C}$ composite xerogels prepared by using the $\mathrm{CF} / \mathrm{RF}$ ratio for $0.00-0.25 \mathrm{~g} / \mathrm{g}$ at $\mathrm{R} / \mathrm{C}=200 \mathrm{~mol} / \mathrm{mol}$ and $\mathrm{R} / \mathrm{W}=0.25 \mathrm{~g} / \mathrm{cm}^{3}$ : (a) $\mathrm{N}_{2}$ adsorption and desorption isotherms at $-196{ }^{\circ} \mathrm{C}$ (open symbols = adsorption; closed symbols = desorption), (b) mesopore size distribution, and (c) micropore size distribution.

Figure 5a indicates the $\mathrm{N}_{2}$ adsorption and desorption isotherms on CCC and the $\mathrm{C} / \mathrm{C}$ composite xerogels at $-196^{\circ} \mathrm{C}$. The shape of every $\mathrm{N}_{2}$ adsorption isotherm is similar. Noticeably, the shape of the $\mathrm{N}_{2}$ adsorption isotherm is different from the previous synthesis conditions in Figures $3 \mathrm{a}$ and $4 \mathrm{a}$. The mesopores are formed by the void among the nanoparticles. The increase in $\mathrm{R} / \mathrm{C}$ ratio increases the nanoparticle sizes, enlarging the mesopore radius $[7,8]$. At $500 \mathrm{~mol} / \mathrm{mol}$ of the $\mathrm{R} / \mathrm{C}$ ratio, the mesopore radius becomes large and macropores can be formed simultaneously. The hysteresis loops become narrow and steep with the larger amounts of $\mathrm{N}_{2}$ adsorbed at the high-pressure ratio related to the large mesopores and macropores, as shown in Figure 5a. On the other hand, the hysteresis loops in Figure 4a are large loops corresponding to the mesopore structure. Here, Figure $5 b$ shows that the mesopores of every carbon specimen have a very large pore radius $\left(r_{\mathrm{p}}>10 \mathrm{~nm}\right)$. Note that Figure $5 \mathrm{~b}$ shows only half of the mesopore size distribution in the $r_{\mathrm{p}}$ term because the $\mathrm{DH}$ method demonstrates the mesopore range. Furthermore, Figure $5 c$ shows that the MicPSD curves of CCC and C00 are identical. 

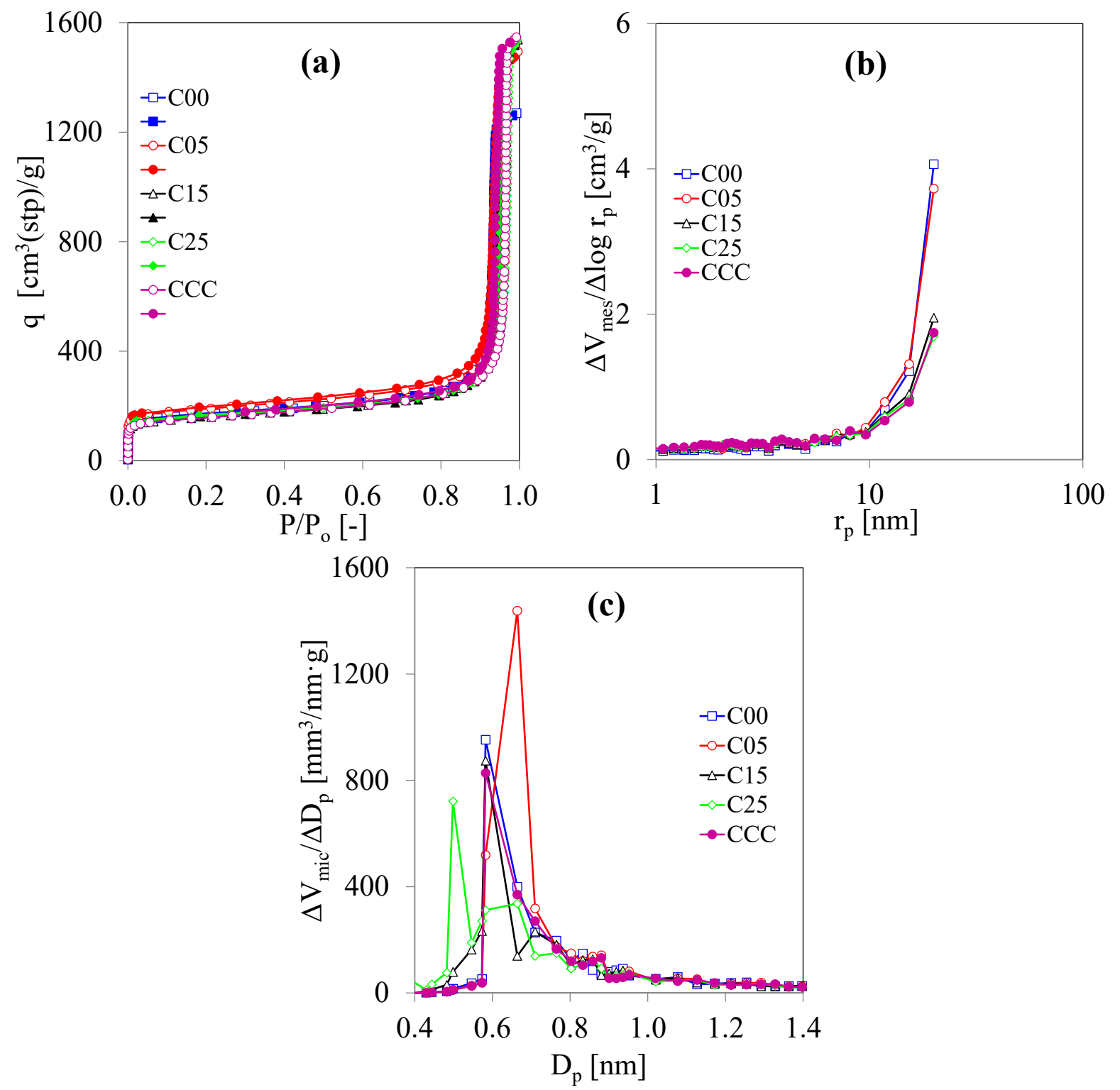

Figure 5. $\mathrm{N}_{2}$ adsorption analysis of $\mathrm{CaF}$ and $\mathrm{C} / \mathrm{C}$ composite xerogels prepared by using the $\mathrm{CF} / \mathrm{RF}$ ratio for $0.00-0.25 \mathrm{~g} / \mathrm{g}$ at $\mathrm{R} / \mathrm{C}=500 \mathrm{~mol} / \mathrm{mol}$ and $\mathrm{R} / \mathrm{W}=0.25 \mathrm{~g} / \mathrm{cm}^{3}$ : (a) $\mathrm{N}_{2}$ adsorption and desorption isotherms at $-196{ }^{\circ} \mathrm{C}$ (open symbols = adsorption; closed symbols = desorption), (b) mesopore size distribution, and (c) micropore size distribution.

Table 2 reports the porous properties of $\mathrm{CaF}$, carbon cryogels, and $\mathrm{C} / \mathrm{C}$ composite xerogels. The results show that $\mathrm{BCC}$ has a larger $V_{\text {mes }}$ value than $\mathrm{B} 00$, but $\mathrm{ACC}$ and CCC have smaller $V_{\text {mes }}$ values than A00 and C00, respectively. Generally, although freeze-drying is better than evaporation to dry the hydrogels, the synthesis conditions of hydrogels also play an important role equal to that of the drying method to determine the porosity of carbon products $[16,20,24]$. For the $C / C$ composite xerogels, A00, A05, and A10 possess porous properties better than those of ACC dried by freeze-drying. Moreover, the

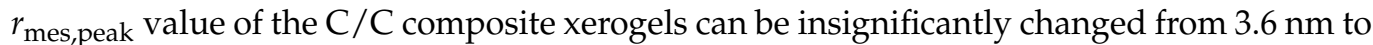
$3.9 \mathrm{~nm}$. The results imply that evaporation drying with solvent exchange using TBA can be effectively applied to the preparation of the $\mathrm{C} / \mathrm{C}$ composite xerogels with an insignificant change of $r_{\text {mes,peak }}$ value. In other words, CF addition can keep the mesopore radius. For the micropore size, the $D_{\text {mic,peak }}$ values of ACC and A00 are equal to the $D_{\text {mic,peak }}$ value of A05 at $0.582 \mathrm{~nm}$, but the $D_{\text {mic,peak }}$ value of A10 is initially deviated to $0.664 \mathrm{~nm}$. Nonetheless, the micropore size is not greatly changed. 
Table 2. Porous properties of $\mathrm{CaF}$ and $\mathrm{C} / \mathrm{C}$ composite xerogels prepared under various synthesis conditions.

\begin{tabular}{ccccccc}
\hline Symbol & $\begin{array}{c}S_{\text {BET }} \\
\left(\mathbf{m}^{2} / \mathbf{g}\right)\end{array}$ & $\begin{array}{c}S_{\text {mic }} \\
\left(\mathbf{m}^{\mathbf{2}} / \mathbf{g}\right)\end{array}$ & $\begin{array}{c}\boldsymbol{V}_{\text {mes }} \\
\left(\mathbf{c m}^{\mathbf{3}} \mathbf{g}\right)\end{array}$ & $\begin{array}{c}\boldsymbol{V}_{\text {mic }} \\
\left(\mathbf{c m}^{3} / \mathbf{g}\right)\end{array}$ & $\begin{array}{c}r_{\text {mes,peak }} \\
(\mathbf{n m})\end{array}$ & $\begin{array}{c}\boldsymbol{D}_{\text {mic,peak }} \\
(\mathbf{n m})\end{array}$ \\
\hline ACC & 590 & 310 & 0.48 & 0.19 & 3.6 & 0.582 \\
A00 & 680 & 360 & 0.60 & 0.22 & 3.6 & 0.582 \\
A05 & 730 & 390 & 0.66 & 0.23 & 3.9 & 0.582 \\
A10 & 680 & 340 & 0.63 & 0.22 & 3.9 & 0.664 \\
\hline BCC & 700 & 350 & 1.04 & 0.22 & 6.2 & 0.664 \\
B00 & 680 & 380 & 0.63 & 0.21 & 4.6 & 0.582 \\
B05 & 660 & 360 & 0.74 & 0.21 & 5.5 & 0.582 \\
B15 & 720 & 390 & 0.85 & 0.23 & 5.5 & 0.582 \\
B25 & 620 & 340 & 0.78 & 0.21 & 5.5 & 0.573 \\
\hline CCC & 590 & 440 & 0.58 & 0.19 & $n$ & 0.582 \\
C00 & 630 & 500 & 0.87 & 0.21 & $>20.02$ & 0.582 \\
C05 & 720 & 560 & 0.88 & 0.23 & $>20.02$ & 0.664 \\
C15 & 590 & 450 & 0.62 & 0.19 & $>20.02$ & 0.582 \\
C25 & 620 & 490 & 0.57 & 0.20 & $>20.02$ & 0.498 \\
\hline CaF & 910 & 890 & 0.13 & 0.28 & 2.5 & 0.498 \\
\hline
\end{tabular}

For other synthesis conditions, however, evaporation drying with solvent exchange using TBA cannot prevent pore shrinkage. The $V_{\text {mes }}$ value of B00 is smaller than the $V_{\text {mes }}$ value of BCC by about $40 \%$, and the mesopore size is also slightly decreased by pore shrinkage, from $6.2 \mathrm{~nm}$ to $4.6 \mathrm{~nm}$. When the $\mathrm{CF}$ addition in the preparation of C/C composites is used, the $V_{\text {mes }}$ value and the mesopore size of the $\mathrm{C} / \mathrm{C}$ composite xerogels (B05, B15, and B25) increase to a greater extent than those of B00. Consequently, the mesopore shrinkage of $C / C$ composite xerogels by evaporation drying can be alleviated

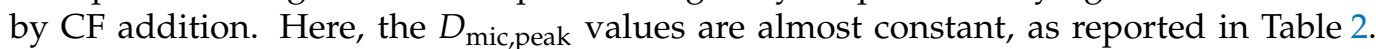
If the $\mathrm{R} / \mathrm{C}$ ratio is increased to $500 \mathrm{~mol} / \mathrm{mol}, \mathrm{C} 00$ has a larger $V_{\text {mes }}$ value than CCC. Nonetheless, the more CF addition herein seemingly decreases the $V_{\text {mes }}$ value. It is found that the $V_{\text {mic }}$ value is slightly increased by evaporation drying with solvent exchange using the application of TBA. The $D_{\text {mic,peak }}$ value also slightly oscillates around $0.582 \mathrm{~nm}$. Therefore, the preparation of $\mathrm{C} / \mathrm{C}$ composite xerogels can maintain the mesopore size and micropore size nearly equivalent to the carbon cryogels at the same RF synthesis conditions. Compared with the carbon cryogel, previous work has illustrated that the $V_{\text {mes }}$ value of a carbon xerogel was significantly decreased by evaporation drying, but the $V_{\text {mic }}$ value could be maintained [25]. Therefore, the CF addition in the preparation of C/C composite xerogels can develop the mesopores and the micropores by evaporation drying with solvent exchange using TBA.

\section{Summary and Conclusions}

The C/C composite xerogels were synthesized from the mixture of RF sol and CF with a slightly basic solution, gelated at $25^{\circ} \mathrm{C}$, cured at $85^{\circ} \mathrm{C}$, exchanged by TBA, dried by evaporation drying, and carbonized at $1000^{\circ} \mathrm{C}$. C/C composite xerogels were prepared by using three $\mathrm{RF}$ sols and several $\mathrm{CF} / \mathrm{RF}$ ratios. The carbon cryogels dried by freeze-drying were also prepared to compare with the normal carbon xerogels. The porous properties and the pore structure of $\mathrm{C} / \mathrm{C}$ composite xerogels were clarified by the $\mathrm{N}_{2}$ adsorption apparatus and scanning electron microscope, respectively. Their porous properties were calculated from the adsorption branch by the BET method, the DH method, the t-plot method, the HK method, and the DR method. The following conclusions were reached.

(a) The preparation of $\mathrm{C} / \mathrm{C}$ composite xerogels does not result in a change in their carbon structure compared to the carbon xerogels and the carbon cryogels at a high $\mathrm{R} / \mathrm{C}$ ratio.

(b) Not only does the $\mathrm{CF}$ addition develop the mesopores of $\mathrm{C} / \mathrm{C}$ composite xerogels, but the $\mathrm{CF}$ addition also maintains the mesopore size and the micropore size to a level 
nearly equivalent to the carbon cryogels under the same RF synthesis conditions by evaporation drying with solvent exchange using TBA.

(c) The mesopore shrinkage of $\mathrm{C} / \mathrm{C}$ composite xerogels during evaporation drying can be alleviated by $\mathrm{CF}$ addition.

(d) Evaporation drying with solvent exchange using TBA can prevent the decrease in micropore volume in the preparation of $\mathrm{C} / \mathrm{C}$ composite xerogels.

Author Contributions: Investigation, K.K.; writing—original draft preparation, K.K.; writingreview and editing, N.S. and H.T. All authors have read and agreed to the published version of the manuscript.

Funding: This research was financially supported by the Thailand Research Fund (Grant No. RSA5980004), the Japan Society for the Promotion of Science (Grant No. P09300), and King Mongkut's Institute of Technology Ladkrabang Research Fund (Grant No. 2564-02-01-004).

Institutional Review Board Statement: Not applicable.

Informed Consent Statement: Not applicable.

Data Availability Statement: The data presented in this study are available on request from the corresponding author.

Conflicts of Interest: The authors declare no conflict of interest.

\section{References}

1. Pekala, R.W. Organic aerogels from the polycondensation of resorcinol with formaldehyde. J. Mater. Sci. 1989, 24, 3221-3227. [CrossRef]

2. Pekala, R.W.; Alviso, C.T.; Kong, F.M.; Hulsey, S.S. Aerogels derived from multifunctional organic monomers. J. Non-Cryst. Solids 1992, 145, 90-98. [CrossRef]

3. Pekala, R.W.; Alviso, C.T. Carbon aerogels and xerogels. Mater. Res. Soc. Symp. Proc. 1992, 270, 3-14. [CrossRef]

4. Pekala, R.W.; Schaefer, D.W. Structure of organic aerogels. 1. Morphology and scaling. Macromolecules 1993, 26, 5487-5493. [CrossRef]

5. Tamon, H.; Ishizaka, H.; Mikami, M.; Okazaki, M. Porous structure of organic and carbon aerogels synthesized by sol-gel polycondensation of resorcinol with formaldehyde. Carbon 1997, 35, 791-796. [CrossRef]

6. Tamon, H.; Ishizaka, H.; Araki, T.; Okazaki, M. Control of mesoporous structure of organic and carbon aerogels. Carbon 1998, 36, 1257-1262. [CrossRef]

7. Pierre, A.C.; Pajonk, G.M. Chemistry of aerogels and their applications. Chem. Rev. 2002, 102, 4243-4265. [CrossRef] [PubMed]

8. Al-Muhtaseb, S.A.; Ritter, J.A. Preparation and Properties of Resorcinol-Formaldehyde Organic and Carbon Gels. Adv. Mater. 2003, 15, 101-114. [CrossRef]

9. Tamon, H.; Ishizaka, H.; Yamamoto, T.; Suzuki, T. Preparation of mesoporous carbon by freeze drying. Carbon 1999, 37, 2049-2055. [CrossRef]

10. Tamon, H.; Ishizaka, H.; Yamamoto, T.; Suzuki, T. Influence of freeze-drying conditions on the mesoporosity of organic gels as carbon precursors. Carbon 2000, 38, 1099-1105. [CrossRef]

11. Tamon, H.; Ishizaka, H.; Yamamoto, T.; Suzuki, T. Freeze drying for preparation of aerogel-like carbon. Drying Technol. 2001, 19, 313-324. [CrossRef]

12. Yamamoto, T.; Nishimura, T.; Suzuki, T.; Tamon, H. Control of mesoporosity of carbon gels prepared by sol-gel polycondensation and freeze drying. J. Non-Cryst. Solids 2001, 288, 46-55. [CrossRef]

13. Mayer, S.T.; Kaschmitter, J.; Pekala, R.W. Method of low pressure and /or evaporative drying of aerogels. U.S. Patent 5420168, 30 May 1995.

14. Job, N.; Pirard, R.; Marien, J.; Pirard, J.-P. Porous carbon xerogels with texture tailored by $\mathrm{pH}$ control during sol-gel process. Carbon 2004, 42, 619-628. [CrossRef]

15. Lin, C.; Ritter, J.A. Effect of synthesis $\mathrm{pH}$ on the structure of carbon xerogels. Carbon 1997, 35, 1271-1278. [CrossRef]

16. Yamamoto, T.; Nishimura, T.; Suzuki, T.; Tamon, H. Effect of drying method on mesoporosity of resorcinol-formaldehyde drygel and carbon gel. Dry. Technol. 2001, 19, 1319-1333. [CrossRef]

17. Hebalkar, N.; Arabale, G.; Sainkar, S.R.; Pradhan, S.D.; Mulla, I.S.; Vijayamohanan, K.; Ayyub, P.; Kulkarni, S.K. Study of correlation of structural and surface properties with electrochemical behaviour in carbon aerogels. J. Mater. Sci. 2005, 40, 3777-3782. [CrossRef]

18. Matos, I.; Fernandes, S.; Guerreiro, L.; Barata, S.; Ramos, A.M.; Vital, J.; Fonseca, I.M. The effect of surfactants on the porosity of carbon xerogels. Microporous Mesoporous Mater. 2006, 92, 38-46. [CrossRef] 
19. Job, N.; Sabatier, F.; Pirard, J.-P.; Crine, M.; Leonard, A. Towards the production of carbon xerogel monoliths by optimizing convective drying conditions. Carbon 2006, 44, 2534-2542. [CrossRef]

20. Job, N.; Thery, A.; Pirard, R.; Marien, J.; Kocon, L.; Rouzaud, J.-N.; Beguin, F.; Pirard, J.-P. Carbon aerogels, cryogels and xerogels: Influence of the drying method on the textural properties of porous carbon materials. Carbon 2005, 43, 2481-2492. [CrossRef]

21. Wu, D.C.; Fu, R.W.; Zhang, S.T.; Dresselhaus, M.S.; Dresselhaus, G. Preparation of low-density carbon aerogels by ambient pressure drying. Carbon 2004, 42, 2033-2039. [CrossRef]

22. Wiener, M.; Reichenauer, G.; Scherb, T.; Fricke, J. Accelerating the synthesis of carbon aerogel precursors. J. Non-Cryst. Solids 2004, 350, 126-130. [CrossRef]

23. Zubizarreta, L.; Arenillas, A.; Dominguez, A.; Menendez, J.A.; Pis, J.J. Development of microporous carbon xerogels by controlling synthesis conditions. J. Non-Cryst. Solids 2008, 354, 817-825. [CrossRef]

24. Czakkel, O.; Marthi, K.; Geissler, E.; Laszlo, K. Influence of drying on the morphology of resorcinol-formaldehyde-based carbon gels. Microporous Mesoporous Mater. 2005, 86, 124-133. [CrossRef]

25. Kraiwattanawong, K.; Tamon, H.; Praserthdam, P. Influence of solvent species used in solvent exchange for preparation of mesoporous carbon xerogels from resorcinol and formaldehyde via subcritical drying. Microporous Mesoporous Mater. 2011, 138, 8-16. [CrossRef]

26. Kraiwattanawong, K.; Sano, N.; Tamon, H. Low-cost production of mesoporous carbon/carbon composite cryogels. Carbon 2011, 49,3404-3411. [CrossRef]

27. Kraiwattanawong, K.; Sano, N.; Tamon, H. Carbon tunnels formed in carbon/carbon composite cryogels. Microporous Mesoporous Mater. 2012, 153, 47-54. [CrossRef]

28. Kraiwattanawong, K.; Sano, N.; Tamon, H. Capacitive performance of binder-free carbon/carbon composite cryogels. Microporous Mesoporous Mater. 2013, 165, 228-233. [CrossRef]

29. Wang, J.; Glora, M.; Petricevic, R.; Saliger, R.; Proebstle, H.; Fricke, J. Carbon cloth reinforced carbon aerogel films derived from resorcinol formaldehyde. J. Porous Mater. 2001, 8, 159-165. [CrossRef]

30. Schmitt, C.; Proebstle, H.; Fricke, J. Carbon cloth-reinforced and activated aerogel films for supercapacitors. J. Non-Cryst. Solids 2001, 285, 277-282. [CrossRef]

31. Fu, R.W.; Zhang, B.; Liu, J.; Weiss, S.; Ying, J.Y.; Dresselhaus, M.S.; Dresselhaus, G.; Satcher, J.H.; Baumann, T.F. Fabrication of activated carbon fibers/carbon aerogels composites by gelation and supercritical drying in isopropanol. J. Mater. Res. 2003, 18, 2765-2773. [CrossRef]

32. Petricevic, R.; Glora, M.; Fricke, J. Planar fibre reinforced carbon aerogels for application in PEM fuel cells. Carbon 2001, 39, 857-867. [CrossRef]

33. Rasines, G.; Lavela, P.; Macías, C.; Zafra, M.C.; Tirado, J.L.; Ania, C.O. Mesoporous carbon black-aerogel composites with optimized properties for the electro-assisted removal of sodium chloride from brackish water. J. Electroanal. Chem. 2015, 741, 42-50. [CrossRef]

34. Feng, J.; Zhang, C.; Feng, J. Carbon fiber reinforced carbon aerogel composites for thermal insulation prepared by soft reinforcement. Mater. Lett. 2012, 67, 266-268. [CrossRef]

35. Dollimore, D.; Heal, G.R. An improved method for the calculation of pore-size distribution from adsorption data. J. Appl. Chem. 1964, 14, 109-114. [CrossRef]

36. Dubinin, M.M.; Radushkevich, L.V. The equation of the characteristic curve of activated charcoal. Dokl. Akad. Nauk. SSSR 1947, 55, 327-329.

37. Lippens, B.C.; de Boer, J.H. Pore system in catalysts. V: The t-method. J. Catal. 1965, 4, 319-323. [CrossRef]

38. Horvath, G.; Kawazoe, K. Method for the calculation of effective pore size distribution in molecular sieve carbon. J. Chem. Eng. Jpn. 1983, 16, 470-475. [CrossRef] 